\title{
Imbalanced phosphorus and nitrogen deposition in China's forests
}

\author{
Enzai Du' ${ }^{1}$, Wim de Vries ${ }^{2,3}$, Wenxuan Han ${ }^{4}$, Xuejun Liu ${ }^{4}$, Zhengbing Yan ${ }^{5}$, and Yuan Jiang ${ }^{1}$ \\ ${ }^{1}$ State Key Laboratory of Earth Surface Processes and Resource Ecology, and College of Resources Science \& Technology, \\ Beijing Normal University, 100875 Beijing, China \\ ${ }^{2}$ Environmental Systems Analysis Group, Wageningen University, P.O. Box 47, 6700 AA Wageningen, the Netherlands \\ ${ }^{3}$ Alterra, Wageningen University and Research Center, P.O. Box 47, 6700 AA Wageningen, the Netherlands \\ ${ }^{4}$ College of Resources and Environmental Sciences, China Agricultural University, 100193 Beijing, China \\ ${ }^{5}$ Department of Ecology, and Key Laboratory for Earth Surface Processes of the Ministry of Education, Peking University, \\ 100871 Beijing, China
}

Correspondence to: Enzai Du (enzaidu@ bnu.edu.cn) and Yuan Jiang (jiangy@ bnu.edu.cn)

Received: 7 December 2015 - Published in Atmos. Chem. Phys. Discuss.: 16 February 2016

Revised: 28 June 2016 - Accepted: 28 June 2016 - Published: 14 July 2016

\begin{abstract}
Acceleration of anthropogenic emissions in China has substantially increased nitrogen $(\mathrm{N})$ deposition during the last 3 decades and may result in an imbalance of atmospheric $\mathrm{N}$ and phosphorus (P) inputs in terrestrial ecosystems. However, the status of $\mathrm{P}$ deposition in China is poorly understood. This study synthesized data on total $\mathrm{P}$ and total $\mathrm{N}$ concentrations in bulk precipitation and throughfall from published literature to assess the characteristics of $\mathrm{P}$ deposition, $\mathrm{N}$ deposition and $\mathrm{N}: \mathrm{P}$ deposition ratio in China's forests. Our results show relatively high mean rates of bulk $\mathrm{P}$ deposition $\left(0.38 \mathrm{~kg} \mathrm{Pha}^{-1} \mathrm{yr}^{-1}\right)$ and total $\mathrm{P}$ deposition $\left(0.69 \mathrm{~kg} \mathrm{Pha}^{-1} \mathrm{yr}^{-1}\right)$, but they were accompanied by even more elevated $\mathrm{N}$ inputs via bulk deposition $\left(16.5 \mathrm{~kg} \mathrm{Nha}^{-1} \mathrm{yr}^{-1}\right)$ and total deposition (21.6 $\mathrm{kg} \mathrm{Nha}^{-1} \mathrm{yr}^{-1}$ ), resulting in high $\mathrm{N}: \mathrm{P}$ ratios in bulk deposition (44.4) and total deposition (32.8). Based on the difference between total deposition and bulk deposition, canopy-captured dry $\mathrm{P}$ and $\mathrm{N}$ deposition was estimated to be $0.31 \mathrm{~kg} \mathrm{Pha}^{-1} \mathrm{yr}^{-1}$ and $5.1 \mathrm{~kg} \mathrm{Nha}^{-1} \mathrm{yr}^{-1}$, respectively. We found significantly higher $\mathrm{P}$ deposition and lower $\mathrm{N}: \mathrm{P}$ ratios at sites nearby than those far from semiarid regions. The estimated bulk and total deposition of $\mathrm{P}$ and $\mathrm{N}$ both showed a significant power-law increase with decreasing distance to the nearest large cities either in the areas nearby or far from semiarid regions. Our results suggest an anthropogenic alternation of regional $\mathrm{P}$ and $\mathrm{N}$ cycling, which may shift large areas of China's forests towards human-induced $\mathrm{P}$ limitation especially in southern China.
\end{abstract}

\section{Introduction}

Nitrogen $(\mathrm{N})$ and phosphorus $(\mathrm{P})$ are essential macronutrients, both of which widely limit primary productivity across terrestrial ecosystems (Elser et al., 2007; Vitousek et al., 2010). External $\mathrm{N}$ inputs to terrestrial ecosystems are driven by biological $\mathrm{N}$ fixation and atmospheric deposition, the latter being increasingly important (Cleveland et al., 2013). Acceleration of anthropogenic $\mathrm{N}$ emissions has substantially increased $\mathrm{N}$ deposition in China during the last 3 decades and aroused widespread concerns about the consequent impacts on various ecosystems (Liu et al., 2011, 2013; Cui et al., 2013). Enhanced N deposition often stimulates forest growth and hence carbon sequestration (Högberg, 2007; De Vries et al., 2009; Thomas et al., 2010), but the expected growth acceleration may be diminished when the accompanied $\mathrm{P}$ supply is deficient (Braun et al., 2010; Li et al., 2016). Soil P availability in terrestrial ecosystems is primarily driven by mineral weathering and atmospheric deposition (Vitousek et al., 2010; Cleveland et al., 2013). Newman (1995) reviewed $\mathrm{P}$ deposition and weathering in global terrestrial ecosystems and estimated a range of $0.07-1.7 \mathrm{~kg} \mathrm{Pha}^{-1} \mathrm{yr}^{-1}$ for $\mathrm{P}$ deposition and $0.01-1.0 \mathrm{~kg} \mathrm{Pha}^{-1} \mathrm{yr}^{-1}$ for $\mathrm{P}$ weathering, indicating that both fluxes are in the same order of magnitude. More recent assessment of observed and modelled P deposition rates on a global scale (Mahowald et al., 2008; Wang et al., 2015) shows a range of $0.01-1.0 \mathrm{~kg} \mathrm{Pha}^{-1} \mathrm{yr}^{-1}$ on land. Despite the significant role of $\mathrm{P}$ deposition, its status and characteristics are poorly understood in China. 
Considering the importance of atmospheric deposition for $\mathrm{N}$ and $\mathrm{P}$ availability, the variation in $\mathrm{N}$ and $\mathrm{P}$ deposition may make a difference in $\mathrm{N}$ - or P-limited ecosystems (Peñuelas et al., 2013). Spatial patterns and temporal trends of $\mathrm{N}$ deposition have recently been well characterized in China (Liu et al., 2013; Du and Liu, 2014; Lu and Tian, 2014; Jia et al., 2014; Du et al., 2014; Xu et al., 2015; Zhu et al., 2015). However, most assessments of $\mathrm{N}$ deposition in China have been based on measurements of bulk deposition (Liu et al., 2013), which substantially underestimates the levels of total deposition because it consists mainly of wet deposition (Kulshrestha et al., 1995; Staelens et al., 2005; Chantara and Chunsuk, 2008). The $\mathrm{N}$ flux in throughfall has been used as a more precise estimate of total deposition (Du et al., 2014, 2015), although it is still an underestimate due to the neglect of $\mathrm{N}$ input by stemflow and the occurrence of canopy $\mathrm{N}$ uptake, especially at lower $\mathrm{N}$ deposition levels (Draaijers et al., 1996; Sparks, 2009). Unlike N, there is a lack of evaluation of $\mathrm{P}$ deposition across China. Furthermore, global-scale P deposition data, including scarce measurements in China, are limited to open-field sites, thus including bulk deposition only (Tipping et al., 2014). Forest canopies increase atmospheric deposition inputs of nutrients to forest ecosystems by trapping dust and particulates (e.g. DeLonge et al., 2008; Das et al., 2011). In the context of low soil $\mathrm{P}$ contents in terrestrial ecosystems across most areas of China (Jiang et al., 1986; Han et al., 2005), the role of $\mathrm{P}$ deposition is relevant because high-level $\mathrm{N}$ deposition, initially stimulating forest growth, is likely shifting large areas of China's forests towards P limitation.

Previous studies have indicated that large cities in China are hotspots of $\mathrm{N}$ deposition (Du et al., 2014, 2015) because the enhancement of $\mathrm{N}$ deposition is primarily driven by anthropogenic emissions from power generation, motor traffic and agricultural activities near urban areas (Liu et al., 2013; Jia et al., 2014). Unlike reactive $\mathrm{N}$, which can form stable gaseous compounds (e.g. $\mathrm{NO}_{x}$ and $\mathrm{NH}_{3}$ ), atmospheric $\mathrm{P}$ occurs primarily in the form of coarse particles and is dominantly derived from mineral dust in natural conditions (Mahowald et al., 2008; Vet et al., 2014). Higher P deposition is thus expected nearby the semiarid regions, which receive large amounts of P-containing particulates transported from neighbouring deserts or barren lands due to the effect of wind erosion (Okin et al., 2004; Mahowald et al., 2008). Based on assumptions of $\mathrm{P}$ partitioning during combustion processes and local deposition, a recent assessment hypothesizes that anthropogenic sources, such as combustion-related emissions, can contribute to over $50 \%$ of the global atmospheric $\mathrm{P}$ budget and make a substantial contribution to global P deposition (Wang et al., 2015), although this result is very sensitive to assumptions about size distribution (Brahney et al., 2015). We can potentially expect higher $\mathrm{P}$ deposition nearby large cities with intensive anthropogenic $\mathrm{P}$ emissions, although the transportation of P-containing dust may lead to distinct urban hotspots of $\mathrm{P}$ deposition nearby and far from the semiarid regions. Here we synthesized data on total $\mathrm{P}$ and total $\mathrm{N}$ concentrations in bulk precipitation and throughfall from published literature to assess the status and characteristics of $\mathrm{P}$ deposition, $\mathrm{N}$ deposition and $\mathrm{N}: \mathrm{P}$ deposition ratios in China's forests. Moreover, we also tested whether spatial patterns of $\mathrm{P}$ deposition showed an increase with decreasing distance to large cities.

\section{Data and methods}

In terms of physics, total atmospheric deposition of elements is divided into (i) wet deposition, being their deposition in rain and snow, and (ii) dry deposition, being their deposition in gases, aerosols and particles. However, most assessments in China have been based on measurements of bulk deposition, which refers to precipitation samples collected by continuously open funnels and includes wet deposition and part of dry deposition because some dry-deposited compounds are inevitably collected during intervening dry periods. In this study, we synthesized data on total $\mathrm{P}$ and total $\mathrm{N}$ concentrations in bulk precipitation and throughfall from published literature to assess the status and characteristics of $\mathrm{P}$ deposition and $\mathrm{N}$ deposition, as discussed in detail below (Sect. 2.2).

\subsection{Datasets}

We collected data from published literature on total $\mathrm{P}$ and total $\mathrm{N}$ concentrations in bulk precipitation and throughfall for typical forests in China, as well as information on site location (latitude and longitude) and annual precipitation. Water samples of bulk precipitation and throughfall were collected by using continuously open funnels and digested to measure total $\mathrm{P}$ and total $\mathrm{N}$ concentrations, which represent the sum of dissolved inorganic forms, dissolved organic forms and insoluble particulate forms. Data were selected only when $\mathrm{P}$ and/or $\mathrm{N}$ concentrations in bulk precipitation and throughfall were measured simultaneously. Data on $\mathrm{P}$ and $\mathrm{N}$ concentrations for each sampling period were either taken directly from tables or digitized from figures using a GetData Graph Digitizer (Version 2.25, http://www.getdata-graph-digitizer. com). If concentration data at one site were measured for more than one forest stand or available for more than 1 year, a volume-weighted mean was calculated and used for further analysis. The distance between the sampling site and the geometric centre of the nearest large city (non-agricultural population $>0.5$ million) was derived using Google Earth for Microsoft Windows (Version 7.1.5.1557, Google Inc., USA).

Our database consisted of 33 sites, which were distributed across the main forest biomes in China (see Fig. S1 and Table S1 in the Supplement for detailed information). Annual precipitation ranged from 500 to $2900 \mathrm{~mm}$. The distance from the sampling sites to the nearest large cities ranged from 5 to $465 \mathrm{~km}$. Using a criterion of a distance of $400 \mathrm{~km}$ to the 
semiarid regions (e.g. grassland), we grouped our datasets into sites nearby semiarid regions $(\mathrm{n}=11)$ and sites far from the semiarid regions $(n=22)$ (Fig. S1).

\subsection{Calculation of bulk deposition, total deposition and canopy-captured dry deposition}

Bulk deposition of total $\mathrm{P}$ and total $\mathrm{N}$ was calculated by multiplying the volume-weighted mean concentration in bulk precipitation with annual precipitation. Canopy-captured dry deposition accumulates during periods without precipitation, and it is washed down during precipitation events. On an annual basis, total deposition equals the sum of $\mathrm{N}$ or $\mathrm{P}$ fluxes in throughfall, stemflow and canopy exchange (Fig. S2). Due to a lack of measured data on canopy exchange and stemflow concentrations, we approximate total deposition by multiplying the volume-weighted mean concentration in throughfall with the sum of throughfall and stemflow water fluxes. To estimate the sum of throughfall and stemflow water fluxes, we establish a database of observed throughfall and stemflow (including data from 28 forested stands from 26 sites; Fig. S3) and explored an empirical equation between precipitation and the sum of throughfall and stemflow (Fig. S4). The sum of throughfall and stemflow water fluxes for each forested site was then estimated from the available bulk precipitation data based on this empirical equation. This method generally underestimates the factual total deposition. First, tree foliage can take up a small proportion of soluble $\mathrm{N}$ and $\mathrm{P}$ in rainwater and gaseous $\mathrm{N}$ (part of dry deposition) (Reddy and Majmudar, 1983; Draaijers et al., 1996; Sparks, 2009). Moreover, $\mathrm{P}$ and $\mathrm{N}$ fluxes in stemflow were underestimated because throughfall concentrations of $\mathrm{N}$ or $\mathrm{P}$ are generally lower than those in stemflow. However, the total element input by stemflow is mostly less than $5 \%$ of that by throughfall (e.g. Talkner et al., 2010), and thus it only introduces a small error to the overall estimate.

Canopy-captured dry deposition, defined as the amounts of dry deposition captured and accumulated in forest canopy during the period without precipitation events, was calculated as the difference between the estimated total deposition and bulk deposition. Our estimate of canopy-captured dry deposition is lower than total dry deposition because a proportion of dry deposition is already included in bulk deposition and the total deposition is likely underestimated.

\subsection{Statistical analysis}

A Shapiro-Wilk normality test was used to test whether data were normally distributed. Data ranges were indicated by the first and third quantile. We used a paired sample $t$ test to test the differences of concentrations and $\mathrm{N}: \mathrm{P}$ ratios between bulk precipitation and throughfall. A Student's $t$ test was used to test the difference of $\mathrm{N}$ deposition levels between sites nearby the semiarid regions $(n=11)$ and far from the semiarid regions $(n=22)$.
Previous studies have indicated that $\mathrm{N}$ deposition shows a power-law increase with decreasing distance to the nearest large cities (Du et al., 2014, 2015). To test the urban hotspot hypothesis of $\mathrm{P}$ deposition, we also used a powerlaw model to explore changes in concentrations and fluxes of total $\mathrm{P}$ with the distance between the sampling site and the nearest large city. The analysis was conducted separately for sites nearby the semiarid regions $(n=11)$ and far from the semiarid regions $(n=22)$. Spatial patterns of $\mathrm{P}$ deposition, $\mathrm{N}$ deposition and $\mathrm{N}: \mathrm{P}$ ratios were illustrated using $\mathrm{Ar}-$ cGIS Desktop (version 9.3, ESRI, USA). All statistical analysis was performed using R software (version 3.1.0; R Development Core Team, 2014, http://www.r-project.org/) with a significance level of $p<0.05$.

\section{Results}

\subsection{Concentrations and deposition of total phosphorus}

Phosphorus concentrations in bulk precipitation and throughfall were characterized by a log-normal distribution (Shapiro-Wilk normality test, $p>0.10$ ). The geometric mean of $\mathrm{P}$ concentration in throughfall $(0.068$, ranging from 0.041 to $0.138 \mathrm{mg} \mathrm{PL}^{-1}$ ) was significantly higher (paired sample $t$ test, $\mathrm{d} f=32, p<0.01$ ), being, on average, 2.18 (1.40-3.11) times of that in bulk precipitation (0.031, ranging from 0.017 to $0.050 \mathrm{mg} \mathrm{PL}^{-1}$ ). Similarly, bulk $\mathrm{P}$ deposition and total $\mathrm{P}$ deposition were also characterized by a log-normal distribution (Shapiro-Wilk normality test, $p>0.10)$, showing geometric means at $0.38(0.21-0.57)$ and $0.69(0.40-1.20) \mathrm{kg} \mathrm{Pha}^{-1} \mathrm{yr}^{-1}$, respectively. The canopycaptured dry $\mathrm{P}$ deposition, calculated as the difference between total deposition and bulk deposition, was estimated at $0.31 \mathrm{~kg} \mathrm{Pha}^{-1} \mathrm{yr}^{-1}$, being comparable to bulk $\mathrm{P}$ deposition (paired sample $t$ test, $\mathrm{d} f=32, p=0.36$ ).

Spatial patterns of bulk $\mathrm{P}$ deposition and total $\mathrm{P}$ deposition showed remarkable heterogeneity, varying by a factor exceeding 4 (Fig. 1a and b). Specifically, geometric means of bulk $\mathrm{P}$ deposition and total $\mathrm{P}$ deposition were estimated to be $0.54(0.39-0.98)$ and $0.97(0.74-1.27) \mathrm{kg} \mathrm{Pha}^{-1} \mathrm{yr}^{-1}$ at the 11 sites nearby the semiarid regions. At the other 22 sites far from the semiarid regions, geometric means of bulk $\mathrm{P}$ deposition and total $\mathrm{P}$ deposition were significantly lower (Student's $t$ test, $\mathrm{d} f=31, p<0.01)$, being $0.31(0.20-0.50)$ and $0.57(0.26-1.05) \mathrm{kg} \mathrm{Pha}^{-1} \mathrm{yr}^{-1}$, respectively.

\subsection{Concentrations and deposition of total nitrogen}

Concentrations and fluxes of total $\mathrm{N}$ were also log-normally distributed (Shapiro-Wilk normality test, $p>0.10$ ). The geometric mean of total $\mathrm{N}$ concentration in bulk precipitation were $1.34(0.88-2.19) \mathrm{mg} \mathrm{N} \mathrm{L}^{-1}$ and increased significantly (paired sample $t$ test, $\mathrm{d} f=31, p<0.01)$ to $2.13(1.23$ 3.87) $\mathrm{mg} \mathrm{N} \mathrm{L}^{-1}$ in throughfall. Geometric means of bulk $\mathrm{N}$ deposition and total $\mathrm{N}$ deposition were 16.5 (9.9-24.2) and 


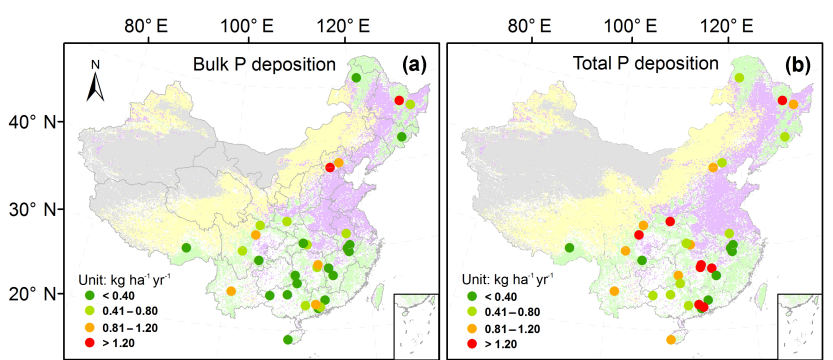

Figure 1. Spatial patterns of (a) bulk $\mathrm{P}$ deposition $\left(\mathrm{kg} \mathrm{ha}^{-1} \mathrm{yr}^{-1}\right)$ and (b) total $\mathrm{P}$ deposition $\left(\mathrm{kg} \mathrm{ha}^{-1} \mathrm{yr}^{-1}\right)$ in China's forests. The background shading in light green, light yellow, light purple and light grey indicates the distribution of forest, grassland (semiarid region), cropland and non-vegetated land, respectively.

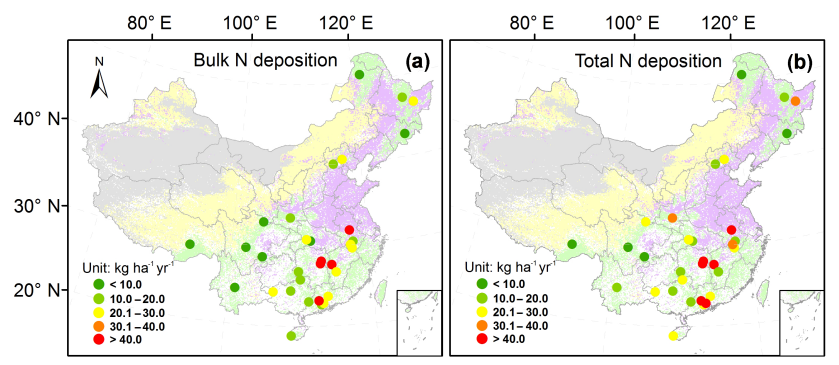

Figure 2. Spatial patterns of (a) bulk $\mathrm{N}$ deposition $\left(\mathrm{kg} \mathrm{ha}^{-1} \mathrm{yr}^{-1}\right)$ and (b) total $\mathrm{N}$ deposition $\left(\mathrm{kg} \mathrm{ha}^{-1} \mathrm{yr}^{-1}\right)$ in China's forests. The background shading in light green, light yellow, light purple and light grey indicates the distribution of forest, grassland (semiarid region), cropland and non-vegetated land, respectively.

21.6 (15.0-31.2) $\mathrm{kg} \mathrm{Nha}^{-1} \mathrm{yr}^{-1}$, leading to an estimate of canopy-captured dry $\mathrm{N}$ deposition of $5.1 \mathrm{~kg} \mathrm{~N} \mathrm{ha}^{-1} \mathrm{yr}^{-1}$. The ratio of total deposition vs. bulk deposition was 1.31 ( 0.98 1.60) for $\mathrm{N}$, which was significantly lower than that $(1.80$, 1.19-2.56) for $\mathrm{P}$ (paired sample $t$ test, $\mathrm{d} f=31, p<0.01$ ). Spatial patterns of bulk $\mathrm{N}$ deposition and total $\mathrm{N}$ deposition showed several regional hotspots near large city clusters in central, eastern and southern China (Fig. 2a and b).

\subsection{Ratios of nitrogen deposition vs. phosphorus deposition}

The $\mathrm{N}: \mathrm{P}$ ratios in bulk precipitation and throughfall were also characterized by a log-normal distribution (ShapiroWilk normality test, $p>0.10$ ). The geometric mean of the $\mathrm{N}$ : P ratio was $44.4(23.1-97.6)$ in bulk precipitation and decreased to 32.8 (18.7-63.6) in throughfall. At the 11 sites nearby the semiarid regions, the geometric mean of the $\mathrm{N}: \mathrm{P}$ ratio in bulk precipitation and throughfall was estimated at 19.3 (9.1-39.9) and 16.2 (10.9-28.6), respectively. However, the $\mathrm{N}: \mathrm{P}$ ratios in bulk precipitation (geometric mean $=64.0$, ranging from 40.9 to 116.7 ) and throughfall (geometric mean $=45.3$, ranging from 25.8 to 74.6 ) were significantly higher (Student's $t$ test, $\mathrm{d} f=31, p<0.01$ ) at the

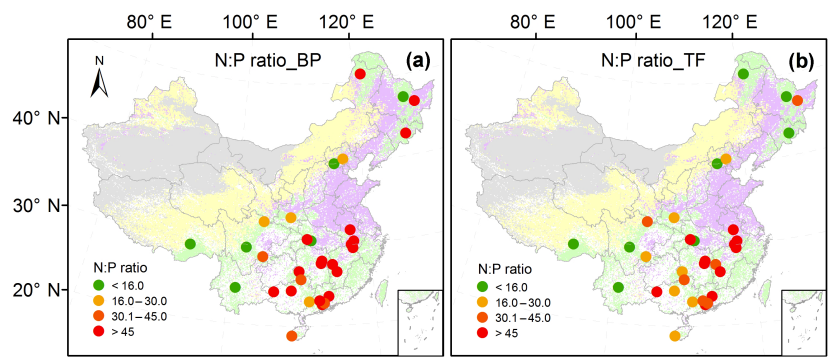

Figure 3. Spatial patterns of $\mathrm{N}: \mathrm{P}$ ratios in (a) bulk precipitation (BP) and (b) throughfall (TF) in China's forests. The background shading in light green, light yellow, light purple and light grey indicates the distribution of forest, grassland (semiarid region), cropland and non-vegetated land, respectively.

other 22 sites far from the semiarid regions, most of which were located in southern China (Fig. 3a and b).

\subsection{Urban hotspots of phosphorus and nitrogen deposition}

Bulk P deposition and total P deposition both showed a significant power-law increase with decreasing distance to the nearest large cities, either nearby or far from the semiarid regions (Figs. 4a, d, 5a, d). In line with the urban hotspot hypothesis, bulk $\mathrm{N}$ deposition and total $\mathrm{N}$ deposition also showed a significant power-law increase with decreasing distance to the nearest large cities (Figs. $4 \mathrm{~b}, \mathrm{e}, 5 \mathrm{~b}, \mathrm{e}$ ). At sites far from semiarid regions, $\mathrm{N}: \mathrm{P}$ ratios in bulk precipitation and throughfall both showed no significant trend with changing distance to the nearest large cities (Fig. 4c, f). However, the $\mathrm{N}$ : $\mathrm{P}$ ratios in throughfall at sites nearby semiarid regions showed a significant power-law increase with decreasing distance to the nearest large cities, while no such trend was found for $\mathrm{N}$ : $\mathrm{P}$ ratios in bulk precipitation (Fig. 5c, f).

\section{Discussion}

\subsection{Phosphorus deposition in China's forests}

Atmospheric P-containing aerosols are either scavenged by precipitation or gravitationally deposited to the ground surface during dry weather. Based on very limited measurements of wet deposition around the world, Vet et al. (2014) summarized that total $\mathrm{P}$ fluxes in wet deposition range from 0.04 to $0.32 \mathrm{~kg} \mathrm{Pha}^{-1} \mathrm{yr}^{-1}$. However, most reported measurements are based on bulk deposition, which includes wet deposition plus a fraction of dry deposition. A recent synthesis of global datasets with 246 sites indicates that bulk deposition of total $\mathrm{P}$ is log-normally distributed and showed a geometric mean of $0.27 \mathrm{~kg} \mathrm{Pha}^{-1} \mathrm{yr}^{-1}$, with total $\mathrm{P}$ being nearly double the amount of inorganic $\mathrm{P}$, which equalled $0.14 \mathrm{~kg} \mathrm{Pha}^{-1} \mathrm{yr}^{-1}$ (Tipping et al., 2014). However, large uncertainties remain in regional estimates due 

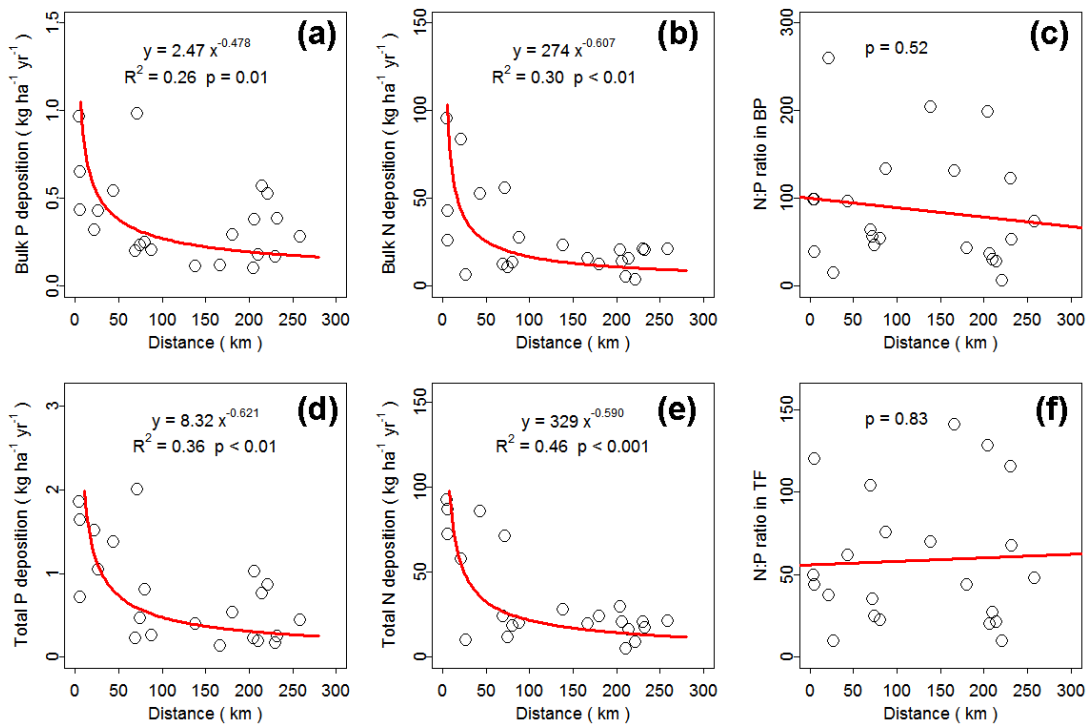

Figure 4. Changes in bulk deposition of $\mathrm{P}$ and $\mathrm{N}\left(\mathrm{kg} \mathrm{ha}^{-1} \mathrm{yr}^{-1}\right)$, total deposition of $\mathrm{P}$ and $\mathrm{N}\left(\mathrm{kg} \mathrm{ha}^{-1} \mathrm{yr}^{-1}\right)$, and $\mathrm{N}: \mathrm{P}$ ratios in bulk precipitation (BP) and throughfall (TF), with the distance to the nearest large cities based on datasets of forested sites far from semiarid regions in China.

to the scarcity of observational data and unevenness of site distribution. For instance, mean bulk deposition of total $\mathrm{P}$ was estimated at $0.12 \mathrm{~kg} \mathrm{Pha}^{-1} \mathrm{yr}^{-1}$ in Asia based on measurements from only 7 sites (Tipping et al., 2014). Using observed data from 33 sites in China's forests, here we show much higher bulk deposition of total $\mathrm{P}$, with a geometric mean of $0.38 \mathrm{~kg} \mathrm{Pha}^{-1} \mathrm{yr}^{-1}$. Overall, our estimate of bulk $\mathrm{P}$ deposition in China is higher than the estimates for Europe $\left(0.22 \mathrm{~kg} \mathrm{Pha}^{-1} \mathrm{yr}^{-1}\right)$, Oceania $\left(0.24 \mathrm{~kg} \mathrm{Pha}^{-1} \mathrm{yr}^{-1}\right)$ and North America $\left(0.29 \mathrm{~kg} \mathrm{Pha}^{-1} \mathrm{yr}^{-1}\right)$ by Tipping et al. (2014), while it is lower than those in South America $\left(0.43 \mathrm{~kg} \mathrm{Pha}^{-1} \mathrm{yr}^{-1}\right)$ and Africa $\left(0.62 \mathrm{~kg} \mathrm{Pha}^{-1} \mathrm{yr}^{-1}\right)$.

Measurements of dry $\mathrm{P}$ deposition are rather scarce. By using limited data of aerosol concentrations and the referential dry-deposition velocity, Vet et al. (2014) estimated that annual dry deposition of total $\mathrm{P}$ on land ranges from 0.01 to $0.62 \mathrm{~kg} \mathrm{Pha}^{-1} \mathrm{yr}^{-1}$. Based on the difference between total deposition and bulk deposition, here we estimated that the mean canopy-captured dry $\mathrm{P}$ deposition was as high as $0.31 \mathrm{~kg} \mathrm{Pha}^{-1} \mathrm{yr}^{-1}$ in China's forests. Although canopycaptured dry $\mathrm{P}$ deposition underestimates dry deposition because a proportion of dry deposition is already included in bulk deposition and the total $\mathrm{N}$ deposition was likely underestimated in this study, it was comparable to bulk deposition $\left(0.38 \mathrm{~kg} \mathrm{Pha}^{-1} \mathrm{yr}^{-1}\right)$ (paired $t$ test, $\mathrm{d} f=32, p=0.36$ ). This result implies that dry deposition is an important pathway of atmospheric $\mathrm{P}$ deposition.

Our assessment shows that the geometric mean of total $\mathrm{P}$ deposition in China's forests was 0.69 (0.401.20) $\mathrm{kg} \mathrm{Pha}^{-1} \mathrm{yr}^{-1}$, being comparable to the modelling results ranging from 0.4 to $1.0 \mathrm{~kg} \mathrm{Pha}^{-1} \mathrm{yr}^{-1}$ in the forested areas in China (Wang et al., 2015). Using the mean to- tal deposition of $0.69 \mathrm{~kg} \mathrm{Pha}^{-1} \mathrm{yr}^{-1}$ and a forested area of $1.76 \times 10^{8}$ ha (Zhang et al., 2010), we further estimated a total atmospheric $\mathrm{P}$ input of $0.12 \mathrm{Tg} \mathrm{Pyr}^{-1}$ in China's forests.

Previous assessments have suggested that large-scale gradients of $\mathrm{P}$ deposition are dust dominated because mineral dust from neighbouring deserts contributes substantially to atmospheric $\mathrm{P}$ deposition in semiarid regions (Okin et al., 2004; Mahowald et al., 2008). Accordingly, our results also show that $\mathrm{P}$ deposition tended to be higher nearby the semiarid regions (Fig. 1a, b). Geometric means of bulk $\mathrm{P}$ deposition and total $\mathrm{P}$ deposition were estimated to be as high as 0.54 (0.39-0.98) and $0.97(0.74-1.27) \mathrm{kg} \mathrm{Pha}^{-1} \mathrm{yr}^{-1}$ nearby the semiarid regions, while the values were significantly lower (Student's $t$ test, $\mathrm{d} f=31, p<0.01$ ) far from the semiarid regions, being $0.31(0.20-0.50)$ and 0.57 (0.261.05) $\mathrm{kg} \mathrm{Pha}^{-1} \mathrm{yr}^{-1}$, respectively. This indicates a significant contribution of dust-borne sources to atmospheric $\mathrm{P}$ deposition in forest ecosystems nearby the semiarid regions.

\subsection{Nitrogen deposition in China's forests}

Our results show high levels of bulk $\mathrm{N}$ deposition and total $\mathrm{N}$ deposition in China's forests, being, on average, 16.5 and $21.6 \mathrm{~kg} \mathrm{Nha}^{-1} \mathrm{yr}^{-1}$, respectively. Most previous assessments of $\mathrm{N}$ deposition in China were either based on bulk deposition or wet deposition (Liu et al., 2013; Du and Liu, 2014; Jia et al., 2014; Du et al., 2014; Zhu et al., 2015; Xu et al., 2015), showing similar values (13.7 to $19.3 \mathrm{~kg} \mathrm{Nha}^{-1} \mathrm{yr}^{-1}$ ) to our estimates based on bulk deposition in China's forests. Although our estimate based on total $\mathrm{N}$ concentrations in throughfall and annual sum of throughfall and stemflow water fluxes is still lower than the factual 

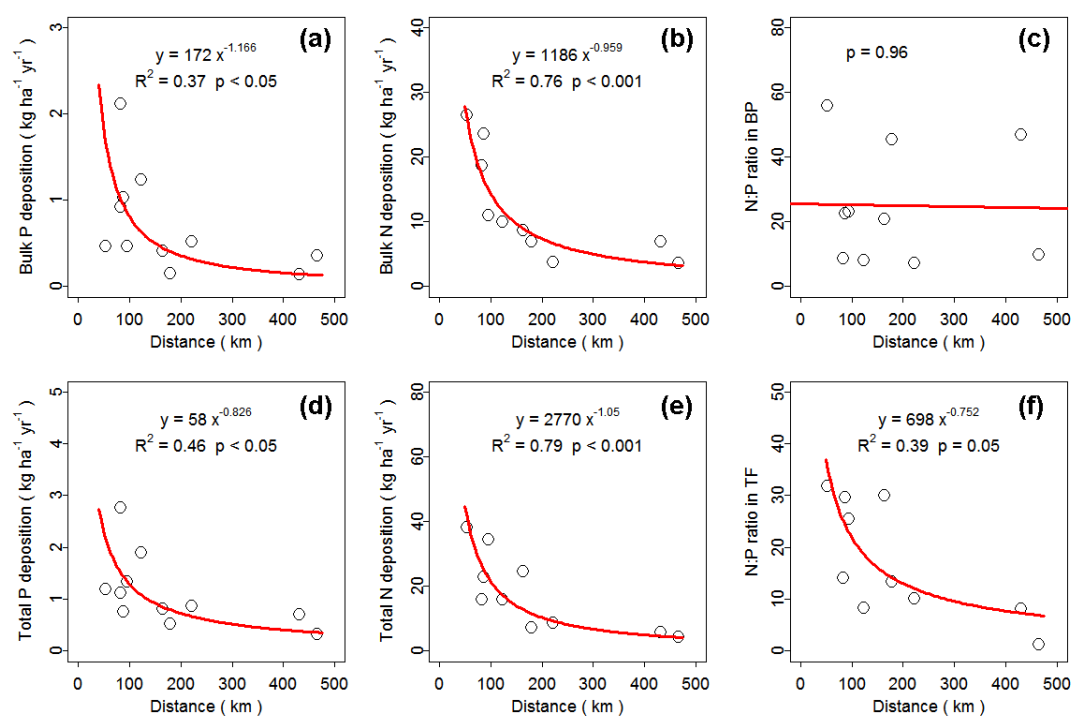

Figure 5. Changes in bulk deposition of $\mathrm{P}$ and $\mathrm{N}\left(\mathrm{kg} \mathrm{ha}^{-1} \mathrm{yr}^{-1}\right)$, total deposition of $\mathrm{P}$ and $\mathrm{N}\left(\mathrm{kg} \mathrm{ha}^{-1} \mathrm{yr}^{-1}\right)$, and $\mathrm{N}$ : $\mathrm{P}$ ratios in bulk precipitation $(\mathrm{BP})$ and throughfall $(\mathrm{TF})$, with the distance to the nearest large cities based on datasets of forested sites nearby semiarid regions in China.

total deposition because tree foliage can take up a small proportion of gaseous $\mathrm{N}$ (part of dry deposition) and soluble $\mathrm{N}$ in rainwater (Draaijers et al., 1996; Sparks, 2009) and the stemflow $\mathrm{N}$ flux is likely underestimated, it is a better proxy of total $\mathrm{N}$ deposition than bulk deposition. Bulk deposition $\left(16.5 \mathrm{~kg} \mathrm{~N} \mathrm{ha}^{-1} \mathrm{yr}^{-1}\right)$ only accounts for $76 \%$ of our estimate of total deposition $\left(21.6 \mathrm{~kg} \mathrm{~N} \mathrm{ha}^{-1} \mathrm{yr}^{-1}\right)$ in China's forests. This difference leads to an estimate of canopy-captured dry $\mathrm{N}$ deposition of at least $5.1 \mathrm{~kg} \mathrm{ha}^{-1} \mathrm{yr}^{-1}$, which is equivalent to $31 \%$ of bulk deposition. The likely underestimation of this value is confirmed by a recent estimate based on airborne concentration measurements via a nationwide $\mathrm{N}$ deposition monitoring network and inferential dry-deposition velocity, which indicated that on average dry $\mathrm{N}$ deposition even exceeded wet/bulk deposition across China (Xu et al., 2015). Based on the mean total $\mathrm{N}$ deposition of $21.6 \mathrm{~kg} \mathrm{~N} \mathrm{ha}^{-1} \mathrm{yr}^{-1}$ and a forested area of $1.76 \times 10^{8}$ ha (Zhang et al., 2010), total $\mathrm{N}$ input via atmospheric deposition was thus estimated to be $3.8 \mathrm{Tg} \mathrm{N} \mathrm{yr}^{-1}$ in China's forests.

\subsection{Urban hotspots of phosphorus and nitrogen deposition}

Bulk P deposition and total P deposition both showed a significant power-law increase with decreasing distance to the nearest large cities, either far from (Fig. 4a, d) or nearby (Fig. 5a, d) the semiarid regions. Anthropogenic sources have been traditionally thought to make only a small contribution to P deposition (Okin et al., 2004; Mahowald et al., 2008), and yet can result in local hotspots of deposition (e.g. Mahowald et al., 2008; Wang et al., 2015). This is in accordance with our study, which indicates that anthropogenic sources near large cities can have significant impacts on the spatial patterns of regional $\mathrm{P}$ deposition. The urban hotspot of $\mathrm{P}$ deposition may be derived from intensive combustion-related emissions near urban areas (Wang et al., 2015) and a shortdistance transfer of P-containing aerosols from P-rich farmland soils (Anderson and Downing, 2006).

Spatial patterns of bulk $\mathrm{N}$ deposition and total $\mathrm{N}$ deposition showed several regional hotspots near large city clusters in central, eastern and southern China (Fig. 2a and b). In line with our previous assessments of inorganic $\mathrm{N}$ deposition (Du et al., 2014, 2015), bulk $\mathrm{N}$ deposition and total $\mathrm{N}$ deposition were also in accordance with the urban hotspot hypothesis (Figs. $4 \mathrm{~b}, \mathrm{e}, 5 \mathrm{~b}, \mathrm{e}$ ). This spatial pattern has been attributed to intensive motor traffic, energy production, waste treatment and agricultural activities (mainly $\mathrm{N}$-fertilizer application and livestock breeding) in and/or near urban areas (Du et al., 2014, 2015). Overall, our results suggest that rapid urbanization in China may have led to a significant alternation of regional $\mathrm{P}$ and $\mathrm{N}$ cycling by enlarging anthropogenic emissions and deposition. In addition, the urban hotspot model is an important approach to describing the way in which large cities shape the spatial pattern of $\mathrm{P}$ and $\mathrm{N}$ deposition. Therefore, it should be incorporated into the modelling of $\mathrm{P}$ and $\mathrm{N}$ deposition on regional scales.

At sites far from semiarid regions, $\mathrm{N}$ : $\mathrm{P}$ ratios in bulk precipitation and throughfall both showed no significant trend with changing distance to the nearest large cities (Fig. 4c, $\mathrm{f}$ ), indicating synchronous changes in $\mathrm{P}$ and $\mathrm{N}$ deposition around these urban hotspots. However, $\mathrm{N}: \mathrm{P}$ ratios in throughfall at sites nearby semiarid regions showed a significant power-law increase with decreasing distance to the 
nearest large cities, while no such trend was found for $\mathrm{N}: \mathrm{P}$ ratio in bulk precipitation (Fig. 5c, f). This distinct trend of $\mathrm{N}: \mathrm{P}$ ratios in bulk precipitation and throughfall suggest a more rapid increase in dry $\mathrm{N}$ deposition than in dry $\mathrm{P}$ deposition with decreasing distance to the nearest large cities.

\subsection{Implications of imbalanced phosphorus and nitrogen deposition}

Our results indicated an imbalance of $\mathrm{N}$ and $\mathrm{P}$ supply by atmospheric nutrient deposition in China's forests. The $\mathrm{N}: \mathrm{P}$ ratio generally showed high values (geometric mean $=44.4$ ) in bulk precipitation in China's forests. Although the N:P ratio decreased in the throughfall, the geometric mean (32.8) was still more than twice that in tree leaves (geometric mean $\mathrm{N}: \mathrm{P}$ ratio $=15)($ Han et al., 2005) and 3 times that in currentyear twigs (geometric mean $\mathrm{N}: \mathrm{P}$ ratio $=10.6$ ) (Yao et al., 2015). It is also much higher than critical N:P ratios related to relative $\mathrm{P}$ limitation in view of forest growth, which are near 15 for coniferous forests and near 25 for deciduous forests (after Mellert and Göttlein, 2012). Compared to the sites nearby semiarid regions, the imbalance of $\mathrm{P}$ and $\mathrm{N}$ deposition was more intense in forests of southern China, showing significantly higher $\mathrm{N}: \mathrm{P}$ ratios in bulk precipitation (geometric mean $=64.0$, ranging 40.9-116.7) and throughfall (geometric mean $=45.3$, ranging 25.8-74.6) (Fig. 3a, b). Moreover, the ratio of total $\mathrm{N}$ vs. total $\mathrm{P}$ may overestimate the relative $\mathrm{P}$ supply vs. $\mathrm{N}$ because a fraction of atmospheric $\mathrm{N}$ deposition is most likely already taken up by the canopy (Draaijers et al., 1996; Sparks, 2009) and a fraction of atmospheric P usually is not bioavailable (Mahowald et al., 2008; Tipping et al., 2014).

Based on a paired analysis of $\mathrm{N}$ and $\mathrm{P}$ concentrations in deposition and lake water, Brahney et al. (2015) showed a clear relationship between $\mathrm{N}: \mathrm{P}$ ratios in the investigated remote alpine lakes and $\mathrm{N}: \mathrm{P}$ ratios in atmospheric deposition. A lack of corresponding datasets of $\mathrm{N}: \mathrm{P}$ ratios in forest vegetation prevents us from testing this correlation for forests but we expect a less clear relationship since atmospheric deposition is the dominant nutrient source in remote lakes, while it is only a relatively small part of the total nutrient supply in forests, most of which is derived from mineralization and/or weathering. Nevertheless, it is likely that the imbalance of $\mathrm{N}$ and $\mathrm{P}$ deposition will lead to an increase in the $\mathrm{N}: \mathrm{P}$ ratio of soils and plant tissue and hence a shift towards humaninduced P limitation in the long term (Peñuelas et al., 2013). Accordingly, a recent assessment has shown that foliar $\mathrm{N}$ concentration of woody plants in China's non-agricultural ecosystems increased significantly between the 1980s and the 2000s, while leaf $\mathrm{P}$ concentration did not change significantly over the same period (Liu et al., 2013). In addition, mean leaf $\mathrm{P}$ concentrations of China's plants were found to be significantly lower than the global averages, most likely due to lower soil P content (Han et al., 2005). Lower leaf $\mathrm{P}$ may constrain the response of photosynthetic capac- ity to leaf $\mathrm{N}$ as P-deficient plants have limited ribulose-1,5bisphosphate regeneration (Reich et al., 2009). Although enhanced $\mathrm{N}$ deposition often stimulates forest growth and carbon sequestration (Högberg, 2007; De Vries et al., 2009; Thomas et al., 2010), the expected growth acceleration can be diminished in P-limited forest ecosystems (Braun et al., 2010; Crowley et al., 2012; Li et al., 2016). Phosphorus limitation may not only constrain future forest growth in response to $\mathrm{N}$ deposition but also lower the projected $\mathrm{CO}_{2}$ fertilization effects on primary productivity (Wieder et al., 2015). Modelling results have also indicated that terrestrial carbon sequestration in China showed a lower response to per unit $\mathrm{N}$ deposition in recent years (Tian et al., 2011). Unless efficient measures are taken to reduce anthropogenic $\mathrm{N}$ emissions in China, the threats of human-induced nutrient imbalance to the health and function of forest ecosystems may keep increasing in the next decades.

\section{Conclusions}

Our results show elevated atmospheric $\mathrm{P}$ deposition in China's forests, but it is accompanied by even more elevated $\mathrm{N}$ deposition. High $\mathrm{N}: \mathrm{P}$ ratios in bulk precipitation and throughfall suggest an imbalance of $\mathrm{P}$ and $\mathrm{N}$ deposition, which likely results in a shift towards $\mathrm{P}$ limitation in forests especially in southern China. Moreover, spatial patterns of $\mathrm{P}$ and $\mathrm{N}$ deposition both showed a strong power-law increase with decreasing distance to the nearest large cities, implying a significant alternation of regional $\mathrm{P}$ and $\mathrm{N}$ cycling by rapid urbanization in China.

China has been cutting down on $\mathrm{NO}_{x}$ emissions since early 2010s (Twelfth Five-year Plan; a full version of the plan is available at http://news.xinhuanet.com/politics/ 2011-03/16/c_121193916.htm), and a stricter national control of air pollution is expected to reduce emissions of $\mathrm{NO}_{x}$ from the combustion of fossil fuels and biofuels in the future (http://news.xinhuanet.com/politics/2013-09/12/ c_117349304.htm). This will consequently lead to a substantial decrease in anthropogenic deposition of oxidized $\mathrm{N}$ (e.g. nitrate). However, the absence of $\mathrm{NH}_{3}$ regulation policy and an increase in meat and dairy consumption may further enhance emissions and deposition of reduced N (e.g. ammonium) in the future. Overall, the issue of the increasing imbalance of $\mathrm{P}$ and $\mathrm{N}$ deposition may further worsen because high levels of $\mathrm{N}$ deposition are expected to continue in the next decades. In order to gain a better understanding of the sources, composition and rates of $\mathrm{P}$ deposition as well as its ecological effects, monitoring networks of atmospheric deposition (e.g. the Nationwide Nitrogen Deposition Monitoring Network, NNDMN, Xu et al., 2015; the Chinese Ecosystem Research Network, CERN, Zhu et al., 2015) are encouraged to include measurements of $\mathrm{P}$ deposition across the country based on standardized sampling protocols and analytical methods. Field observations and manipulated exper- 
iments should be conducted to assess the impacts of nutrient imbalance on the health and function of China's forest ecosystems. Moreover, better forest management strategies should be adopted to avoid a loss in forestry production from the human-induced $\mathrm{P}$ and $\mathrm{N}$ imbalance.

\section{Data availability}

See Sect. 2.1 for further information.

\section{The Supplement related to this article is available online at doi:10.5194/acp-16-8571-2016-supplement.}

Author contributions. Enzai Du and Wim de Vries conceived the idea. Enzai Du conducted data analysis and prepared the manuscript. Wim de Vries, Yuan Jiang, Wenxuan Han, Xuejun Liu and Zhengbing Yan reviewed and edited the manuscript.

Acknowledgements. This study was supported by the National Natural Science Foundation of China (31400381 and 40425007) and the Fundamental Research Funds for the Central Universities (Youth Scholars Program of Beijing Normal University, 2015NT08) and the Open Foundation of Key Laboratory for Earth Surface Processes of the Ministry of Education (201401).

Edited by: F. Dentener

Reviewed by: two anonymous referees

\section{References}

Anderson, K. A. and Downing, J. A.: Dry and wet atmospheric deposition of nitrogen, phosphorus and silicon in an agricultural region, Water Air Soil Poll., 176, 351-374, 2006.

Brahney, J., Mahowald, N., Ward, D. S., Ballantyne, A. P., and Neff, J. C.: Is atmospheric phosphorus pollution altering global alpine Lake stoichiometry?, Global Biogeochem. Cy., 29, 1369-1383, 2015.

Braun, S., Thomas, V. F., Quiring, R., and Flückiger, W.: Does nitrogen deposition increase forest production? The role of phosphorus, Environ. Pollut., 158, 2043-2052, 2010.

Chantara, S. and Chunsuk, N.: Comparison of wet-only and bulk deposition at Chiang Mai (Thailand) based on rainwater chemical composition, Atmos. Environ., 42, 5511-5518, 2008.

Cleveland, C. C., Houlton, B. Z., Smith, W. K., Marklein, A. R., Reed, S. C., Parton, W., Del Grosso, S. J., and Running, S. W.: Patterns of new versus recycled primary production in the terrestrial biosphere, P. Natl. Aca. Sci. USA, 110, 12733-12737, 2013.

Crowley, K. F., McNeil, B. E., Lovett, G. M., Canham, C. D., Driscoll, C. T., Rustad, L. E., Denny, E., Hallett, R. A., Arthur, M. A., Boggs, J. L., Goodale, C. L., Kahl, J. S., McNulty, S. G.,
Ollinger, S. V., Pardo, L. H., Schaberg, P. G., Stoddard, J. L., Weand, M. P., and Weathers, K. C.: Do nutrient limitation patterns shift from nitrogen toward phosphorus with increasing nitrogen deposition across the northeastern United States?, Ecosystems, 15, 940-957, 2012.

Cui, S. H., Shi, Y. L., Groffman, P. M., Schlesinger, W. H., and Zhu, Y. G.: Centennial-scale analysis of the creation and fate of reactive nitrogen in China (1910-2010), P. Natl. Acad. Sci. USA, 110, 2052-2057, 2013.

Das, R., Lawrence, D., D’Odorico, P., and DeLonge, M.: Impact of land use change on atmospheric $P$ inputs in a tropical dry forest, J. Geophys. Res., 116, G01027, doi:10.1029/2010JG001403, 2011.

DeLonge, M., D’Odorico, P., and Lawrence, D.: Feedbacks between phosphorous deposition and canopy cover: the emergence of multiple stable states in dry tropical forests, Glob. Change Biol., 14, 154-160, 2008.

De Vries, W., Solberg, S., Dobbertin, M., Sterbad, H., Laubhannd, D., van Oijene, M., Evansf, C., Gunderseng, P., Krosa, J., Wamelinka, G. W. W., Reindsa, G. J., and Sutton, M. A.: The impact of nitrogen deposition on carbon sequestration by European forests and heathlands, Forest Ecol. Manage., 258, 1814-1823, 2009.

Draaijers, G. P. J., Erisman, J. W., Sprangert, T., and Wyers, G. P.: The application of throughfall measurements for atmospheric deposition monitoring, Atmos. Environ., 30, 3349-3361, 1996.

Du, E., Jiang, Y., Fang, J., and de Vries, W.: Inorganic nitrogen deposition in China's forests: Status and characteristics, Atmos. Environ., 98, 474-482, 2014.

Du, E., de Vries, W., Liu, X., Fang, J., Galloway, J. N. and Jiang, Y.: Spatial boundary of urban "acid islands" in southern China, Sci. Rep., 5, 12625, doi:10.1038/srep12625, 2015.

Du, E. Z. and Liu, X. J.: High rates of wet nitrogen deposition in China: A synthesis, in: Nitrogen Deposition, Critical Loads and Biodiversity, edited by: Sutton, M. A., Mason, K. E., Sheppard, L. J., Sverdrup, H., Haeuber, R., Hicks, W. K., Springer, the Netherlands, 49-56, 2014.

Elser, J. J., Bracken, M. E., Cleland, E. E., Gruner, D. S., Harpole, W. S., Hillebrand, H., Ngai J. T., Seabloom, E. W., Shurin, J. B., and Smith, J. E.: Global analysis of nitrogen and phosphorus limitation of primary producers in freshwater, marine and terrestrial ecosystems, Ecol. Lett., 10, 1135-1142, 2007.

Han, W., Fang, J., Guo, D., and Zhang, Y.: Leaf nitrogen and phosphorus stoichiometry across 753 terrestrial plant species in China, New Phytol., 168, 377-385, 2005.

Högberg, P.: Environmental Science: Nitrogen impacts on forest carbon, Nature, 447, 781-782, 2007.

Jia, Y., Yu, G., He, N., Zhan, X., Fang, H., Sheng, W., Zuo, Y., Zhang, D., and Wang, Q.: Spatial and decadal variations in inorganic nitrogen wet deposition in China induced by human activity, Sci. Rep., 4, 3763, doi:10.1038/srep03763, 2014.

Jiang, B., Lu, R., and Li, Q.: Map of soil phosphorus potential of China, in: Institute of Soil Science, Academia Sinica, The Soil Atlas of China, Beijing, China: Cartographic Publishing House, 36, 1986.

Kulshrestha, U. C., Sarkar, A. K., Srivastava, S. S., and Parashar, D. C.: Wet-only and bulk deposition studies at New Delhi (India), Water Air Soil Poll., 85, 2137-2142, 1995. 
Li, Y., Niu, S., and Yu, G.: Aggravated phosphorus limitation on biomass production under increasing $\mathrm{N}$ addition: A metaanalysis, Glob. Change Biol., 22, 934-943, 2016.

Liu, X., Duan, L., Mo, J., Du, E., Shen, J., Lu, X., Zhang, Y., Zhou, X., He, C., and Zhang, F: Nitrogen deposition and its ecological impact in China: An overview, Environ. Pollut., 159, 2251-2264, 2011.

Liu, X., Zhang, Y., Han, W., Tang, A., Shen, J., Cui, Z., Vitousek, P., Erisman, J. W., Goulding, K., Christie, P., Fangmeier, A., and Zhang, F.: Enhanced nitrogen deposition over China, Nature, 494, 459-462, 2013.

Lu, C. and Tian, H.: Half-century nitrogen deposition increase across China: A gridded time-series data set for regional environmental assessments, Atmos. Environ., 97, 68-74, 2014.

Mahowald, N., Jickells, T. D., Baker, A. R., Artaxo, P., BenitezNelson, C. R., Bergametti, G., Bond, T. C., Chen, Y., Cohen, D. D., Herut, B., Kubilay, N., Losno, R., Luo, C., Maenhaut, W., McGee, K. A., Okin, G. S., Siefert, R. L., and Tsukuda, S.: Global distribution of atmospheric phosphorus sources, concentrations, and deposition rates, and anthropogenic impacts, Global Biogeochem. Cy., 22, GB4026, doi:10.1029/2008GB003240, 2008.

Mellert, K. H. and Göttlein, A.: Comparison of new foliar nutrient thresholds derived from van den Burg's literature compilation with established central European references, Eur. J. Forest Res., 131, 1461-1472, 2012.

Newman, E. I.: Phosphorus inputs to terrestrial ecosystems, J. Ecol., 83, 713-726, 1995.

Okin, G. S., Mahowald, N., Chadwick, O. A., and Artaxo, P.: Impact of desert dust on the biogeochemistry of phosphorus in terrestrial ecosystems, Global Biogeochem. Cy., 18, GB2005, doi:10.1029/2003GB002145, 2004.

Peñuelas, J., Poulter, B., Sardans, J., Ciais, P., van der Velde, M., Bopp, L., Boucher, O., Godderis, Y., Hinsinger, P., Llusia, J., Nardin, E., Vicca, S., Obersteiner, M., and Janssens, I. A.: Human-induced nitrogen-phosphorus imbalances alter natural and managed ecosystems across the globe, Nat. Commun., 4, 2934, doi:10.1038/ncomms3934, 2013.

Reddy, S. E. and Majmudar, A. M.: Response of mango (Mangifera indica L.) to foliar application of phosphorus, Fert. Res., 4), 281285, 1983

Reich, P. B., Oleksyn, J., and Wright, I. J.: Leaf phosphorus influences the photosynthesis-nitrogen relation: a cross-biome analysis of 314 species, Oecologia, 160, 207-212, 2009.

Sparks, J. P.: Ecological ramifications of the direct foliar uptake of nitrogen, Oecologia, 159, 1-13, 2009.

Staelens, J., De Schrijver, A., Van Avermaet, P., Genouw, G., and Verhoest, N.: A comparison of bulk and wet-only deposition at two adjacent sites in Melle (Belgium), Atmos. Environ., 39, 7$15,2005$.

Talkner, U., Krämer I., Hölscher D., and Beese, F. O.: Deposition and canopy exchange processes in central-German beech forests differing in tree species diversity, Plant Soil, 336, 405-420, 2010.

Thomas, R. Q., Canham, C. D., Weathers, K. C., and Goodale, C.L.: Increased tree carbon storage in response to nitrogen deposition in the US, Nat. Geosci., 3, 13-17, 2010.
Tian, H., Melillo, J., Lu, C., Kicklighter, D., Liu, M., Ren, W., Xu, X., Chen, G., Zhang, C., Pan, S., Liu, J., and Running, S.: China's terrestrial carbon balance: contributions from multiple global change factors, Global Biogeochem. Cy., 25, GB1007, doi:10.1029/2010GB003838, 2011.

Tipping, E., Benham, S., Boyle, J. F., Crow, P., Davies, J., Fischer, U., Guyatt H., Helliwell R., Jackson-Blake L., Lawlor A J., Monteith D. T., and Toberman, H.: Atmospheric deposition of phosphorus to land and freshwater, Environ. Sci.-Proc. Imp., 16, 1608-1617, 2014.

Vet, R., Artz, R. S., Carou, S., Shaw, M., Ro, C. U., Aas, W., Baker, A., Bowersox, V. C., Dentener, F., Galy-Lacaux, C., Hou, A., Pienaar, J. J., Gillett, R., Forti, M. C., Gromov, S., Hara, H., Khodzher, T., Mahowald, N., Nickovic, S., Rao, P. S. P., and Reid, N. W.: A global assessment of precipitation chemistry and deposition of sulfur, nitrogen, sea salt, base cations, organic acids, acidity and pH, and phosphorus, Atmos. Environ., 93, $3-$ 100, 2014.

Vitousek, P. M., Porder, S., Houlton, B. Z., and Chadwick, O. A.: Terrestrial phosphorus limitation: mechanisms, implications, and nitrogen-phosphorus interactions, Ecol. Appl., 20, 5-15, 2010.

Wang, R., Balkanski, Y., Boucher, O., Ciais, P., Peñuelas, J., and Tao, S.: Significant contribution of combustion-related emissions to the atmospheric phosphorus budget, Nat. Geosci., 8, 48-54, 2015.

Wieder, W. R., Cleveland, C. C., Smith, W. K., and Todd-Brown, K.: Future productivity and carbon storage limited by terrestrial nutrient availability, Nat. Geosci., 8, 441-444, 2015.

Xu, W., Luo, X. S., Pan, Y. P., Zhang, L., Tang, A. H., Shen, J. L., Zhang, Y., Li, K. H., Wu, Q. H., Yang, D. W., Zhang, Y. Y., Xue, J., Li, W. Q., Li, Q. Q., Tang, L., Lu, S. H., Liang, T., Tong, Y. A., Liu, P., Zhang, Q., Xiong, Z. Q., Shi, X. J., Wu, L. H., Shi, W. Q., Tian, K., Zhong, X. H., Shi, K., Tang, Q. Y., Zhang, L. J., Huang, J. L., He, C. E., Kuang, F. H., Zhu, B., Liu, H., Jin, X., Xin, Y. J., Shi, X. K., Du, E. Z., Dore, A. J., Tang, S., Collett Jr., J. L., Goulding, K., Sun, Y. X., Ren, J., Zhang, F. S., and Liu, X. J.: Quantifying atmospheric nitrogen deposition through a nationwide monitoring network across China, Atmos. Chem. Phys., 15, 12345-12360, doi:10.5194/acp-15-12345-2015, 2015.

Yao, F., Chen, Y., Yan, Z., Li, P., Han, W., and Fang, J.: Biogeographic patterns of structural traits and $\mathrm{C}: \mathrm{N}: \mathrm{P}$ stoichiometry of tree twigs in China's forests, PloS One, 10, e0116391, doi:10.1371/journal.pone.0116391, 2015.

Zhang, Z. Q., Wang, C., Wang, F., Wen, Q., Zuo, L., Dong, T., Zhou, W., Zhang, S., Wu, S., and Yan, C.: Remote Sensing Monitoring of Land Cover in China. Planet Map Publishing House: Beijing, China, 7-8, 2010.

Zhu, J., He, N., Wang, Q., Yuan, G., Wen, D., Yu, G., and Jia, Y.: The composition, spatial patterns, and influencing factors of atmospheric wet nitrogen deposition in Chinese terrestrial ecosystems, Sci. Total Environ., 511, 777-785, 2015. 